JEL I00, O10, Q01

\title{
Achieving sustainable development: a baseline analysis of Western and Eastern European countries
}

\author{
Ya.A. Lopatkova \\ Ural Federal University, Ekaterinburg, Russia; iana.lopatkova@urfu.ru
}

\begin{abstract}
Relevance. Sustainable development is now an increasingly important topic on the global agenda, which received much attention in connection with the adoption of the 2030 Agenda for Sustainable Development and the Sustainable Development Goals (SDGs). Research objectives. The article aims to contribute to the understanding of sustainability expansion and SDGs achievement in Europe by comparing the differences between Western and Eastern European countries. Data and methods. The study relies on descriptive statistics and comparative analysis of sustainable development results in Western (18) and Eastern European (21) countries. The parametric Student's $t$-distribution test and non-parametric $U$ Mann-Whitney test were used to examine the significance of the differences between Western and Eastern European countries. Results. Sustainable development in Eastern and Western European countries is affected by various economic, social and environmental processes. The SDGs in Western European countries is achieved mostly in the social and economic spheres while in the Eastern European countries, in social and environmental spheres. Although Europe leads globally on sustainability, it still faces significant challenges in reaching the SDGs. Conclusions. European countries are compared in order to identify the main SDGs directions and constraints in the current state of sustainability achievement. Research findings can be useful for adjustment of the integrated sustainable development strategy at the global and national levels.
\end{abstract}

\section{KEY WORDS}

sustainability, sustainable development, sustainable development goals (SDGs), Europe, Western and Eastern Europe

\section{FOR CITATION}

Lopatkova, Ya.A. (2021) Connectivity of regional systems of consumer goods reproduction. R-economy, 7(1), 18-27. doi: 10.15826/recon.2021.7.1.002.

\section{Достижение устойчивого развития: анализ исходных условий стран Западной и Восточной Европы}

\author{
Я.А. Лопаткова \\ Уральский федеральный университет, Екатеринбург, Россия; iana.lopatkova@urfu.ru
}

\section{АННОТАЦИЯ}

Актуальность. В настоящее время устойчивое развитие становится все более важной темой в глобальной повестке дня, которой уделяется большое внимание в связи с принятием Повестки дня в области устойчивого развития на период до 2030 года и Целей устойчивого развития (ЦУР). Цель исследования. Статья направлена на содействие пониманию расширения устойчивости и достижения ЦУР в Европе путем сравнения различий между странами Западной и Восточной Европы. Данные и методы. Исследование опирается на описательную статистику и сравнительный анализ результатов устойчивого развития в странах Западной (18) и Восточной Европы (21). Параметрический критерий $t$-распределения Стьюдента и непараметрический $U$-критерий Манна-Уитни использовались для проверки значимости различий между странами Западной и Восточной Европы. Результаты. На устойчивое развитие в странах Восточной и Западной Европы влияют различные экономические, социальные и экологические процессы. ЦУР в странах Западной Европы достигается в основном в социальной и экономической сфеpax, а в странах Восточной Европы - в социальной и экологической сферах. Хотя Европа является лидером в мире по устойчивости, она по-прежнему сталкивается со значительными проблемами в достижении ЦУР. Выводы. Европейские страны сравниваются, чтобы определить основные направления и ограничения ЦУР в текущем состоянии достижения устойчивости. Результаты исследования могут быть полезны для корректировки комплексной стратегии устойчивого развития на глобальном и национальном уровнях.

\section{КЛЮЧЕВЫЕ СЛОВА}

устойчивость, устойчивое развитие, цели устойчивого развития (ЦУР), Европа, Западная и Восточная Европа

\section{ДЛЯ ЦИТИРОВАНИЯ}

Lopatkova, Ya.A. (2021)

Connectivity of regional systems of consumer goods reproduction. R-economy, 7(1), 18-27. doi: 10.15826/recon.2021.7.1.002. 


\section{Introduction}

Sustainable development with its three dimensions - economic, social and environmental has recently acquired great importance on the international agenda. The sustainable development framework includes 17 Sustainable Development Goals (SDGs), which cover a wide range of issues and aim to find effective solutions to the complex challenges of modern society that require an interdisciplinary perspective (Secundo et al., 2020).

Economists believe that countries will be able to make only a limited progress towards sustainable development by 2030. Moreover, the gap of sustainable development between developed and developing countries has expanded. Many researchers study the positive and negative factors that influence sustainable development such as national development strategies and priorities, international aid policies, allocation of financial resources and the level of technological development (Lopatkova et al., 2019; Moyer \& Hedden, 2020; Schmidt-Traub et al., 2017). Moreover, the level of SDGs achievement as well as global and national priorities may change drastically due to the novel coronavirus pandemic (Solberg \& Akufo-Addo, 2020).

The purpose of this paper is to evaluate the current state of SDGs achievement by Western and Eastern European countries in order to identify the main directions and constraints of strategic sustainability through data gathering, monitoring and assessing. This research goal includes the following objectives: (1) to analyze the current state of global sustainability; (2) to evaluate dynamics and achievement of SDGs in Europe; and (3) to identify the priorities in sustainable strategies in Western and Eastern European countries.

\section{Theoretical background}

\section{The concept and measurement of sustainable development}

The concept of sustainable development is linked to globalization, technological pressure, creation of global information space, and depletion of natural resources. Sustainable development is a multi-dimensional concept which focuses on three interdependent elements: economic development, social environmental development and protection (Belyaeva \& Lopatkova, 2020; Kwatra et al., 2020) From the very beginning, however, this concept has received various interpretations and has been criticized on different grounds (Kalin, 2018).
At the first stage (1950s - 1980s), the concept of sustainable development was characterized by a gap between economic development and environment degradation. In this period, the ecocentric approach prevailed and the negative impact of socio-economic development on the environment was emphasized. Numerous studies and conferences devoted to the issue of long-term development in accordance with the environmental conservation principles were conducted (Belyaeva \& Lopatkova, 2020; Kalin, 2018; Kuznetsova, 2013).

The concept of sustainable development has become increasingly widespread after the Brundtland Report released by the World Commission on Environment and Development in 1987 (UN, 2015). Sustainable development was defined as development that meets the needs of the present without compromising the ability of future generations to satisfy their needs. According to the Report, the new approach to sustainable development is based not only on the conservation of the environment, but also on ensuring human needs and adjusting the balance between social and economic development. Moreover, large companies began to aim for sustainable development, aligning corporate goals with those of communities and the planet. One of the important stages in the formation of business sustainability is the standardisation of non-financial reporting and assessment of the contribution of companies to sustainability (e.g. ISO, GRI) (Belyaeva \& Lopatkova, 2020).

This period was followed by the integration stage, which lasts until today. The "Rio + 20 " Conference on Sustainable Development (2012) was a milestone event where an agenda was formulated to reaffirm the commitment to the Millennium Development Goals, which were the forerunners of the SDGs presented in September 2015. Thus, the UN formalized 17 goals and 169 targets of global sustainability (UN, 2015). The concept of sustainable development has become a key element of global policy combining socio-economic and environmental management.

The modern period implies cooperation between the public and private sectors, even small and medium-sized enterprises (Belyaeva \& Lopatkova, 2020; Karlstorm, 2018). The concept of sustainable development has undergone some changes from the traditional scientific view based on the moral and ethical principles of the ancient world toward an integrated perspective. Thus, it has adapted to the modern requirements of a complex global environment. Its fundamental princi- 
ples have contributed to the growing awareness of the complex interdependence between the global pillars - society, economy and environment (Kalin, 2018). Joint efforts need to be taken by the key players (United Nations, governments, private sector, and civil society organizations) in terms of awareness and management to achieve global sustainability (Mensah \& Casadevall, 2019).

The concept of sustainable development is constantly expanding, as new aspects of modern development, new goals and indicators are being added (Kwatra et al., 2020), for example, the 18 th SDG on animal health, welfare and rights (Visseren-Hamaker, 2020).

Table 1

Formation of the sustainable development concept

\begin{tabular}{|l|l|}
\hline \multicolumn{1}{|c|}{ Phase } & \multicolumn{1}{c|}{ Approach and description } \\
\hline $\begin{array}{l}\text { Initial stage } \\
(1950 \text { s }-1980 s)\end{array}$ & $\begin{array}{l}\text { Ecocentric approach: environmental } \\
\text { issues are recognized as fundamental } \\
\text { elements }\end{array}$ \\
\hline $\begin{array}{l}\text { Socio-economic } \\
\text { stage } \\
(1980-1990 s)\end{array}$ & $\begin{array}{l}\text { Anthropocentric approach: society fits } \\
\text { into the life of nature and influences it }\end{array}$ \\
\cline { 2 - 2 } $\begin{array}{l}\text { Corporate social responsibility: } \\
\text { business is responsible for the social, } \\
\text { environmental and economic conse- } \\
\text { quences of its activities }\end{array}$ \\
\hline $\begin{array}{l}\text { Integrated stage } \\
(1990 s-\text { until now) }\end{array}$ & $\begin{array}{l}\text { Holistic sustainability development } \\
\text { based on economic, environmental, } \\
\text { and social development patterns. UN } \\
\text { Agenda for Sustainable Development: } \\
\text { 2030 }\end{array}$ \\
\hline
\end{tabular}

Source: compiled on the basis of Belyaeva \& Lopatkova, 2020; Kalin, 2018; Kuznetsova, 2013

One of the main tools for achieving sustainability is the availability of indicators that contribute to the correct measurement of effectiveness in various aspects of sustainable development (Dang \& Serajuddin, 2019; Kwatra et al., 2020). There is an ongoing debate about how to measure sustainable performance (Miola \& Schiltz, 2019). Various indicators and methods are used to assess sustainability. Therefore, the study raises the question of the use of a variable to assess the global, regional and national level of sustainable development according to the comprehensive approach. Miola \& Schiltz (2019) argued that the relative position of a country depends almost entirely on the chosen method and indicators; different assessment methods can lead to different results of the country's performance (Dang \& Serajuddin, 2019). There is a set of indicators used both to measure global progress towards sustainability and the relative performance of countries. Each of the global indices (see Table 2) focuses on one or two dimensions; one ex- ception is the SDGs Index. Schmidt-Traub et al. (2017) found out that the SDG Index is strongly correlated with the human development index (HDI) and per capita gross domestic product (GDP). The correlation is the weakest with the Index of Economic Freedom (EF) and the Global Peace Index (GPI) (Schmidt-Traub et al., 2017).

Table 2

Sustainable Development Indicators

\begin{tabular}{|l|l|l|}
\hline $\begin{array}{c}\text { Research } \\
\text { level }\end{array}$ & \multicolumn{1}{|c|}{$\begin{array}{c}\text { Examples } \\
\text { of indicators }\end{array}$} & \multicolumn{1}{c|}{$\begin{array}{c}\text { Sustainable } \\
\text { development pillars }\end{array}$} \\
\hline $\begin{array}{l}\text { Global } \\
\text { and na- } \\
\text { tional }\end{array}$ & $\begin{array}{l}\text { GDP per capita } \\
\text { Living Planet Index } \\
\text { (LPI) }\end{array}$ & Economic development \\
\cline { 2 - 3 } & $\begin{array}{l}\text { Euman Development } \\
\text { Index (HDI) }\end{array}$ & $\begin{array}{l}\text { Economical development } \\
\text { development }\end{array}$ \\
\cline { 2 - 3 } & $\begin{array}{l}\text { Environment Perfor- } \\
\text { mance Index (EPI) }\end{array}$ & $\begin{array}{l}\text { Ecological + social } \\
\text { development }\end{array}$ \\
\cline { 2 - 3 } & $\begin{array}{l}\text { Happy Planet Index } \\
\text { (HPI) }\end{array}$ & $\begin{array}{l}\text { Ecological + social } \\
\text { development }\end{array}$ \\
\cline { 2 - 4 } & $\begin{array}{l}\text { Index of Economic } \\
\text { Freedom }\end{array}$ & $\begin{array}{l}\text { Economic + social } \\
\text { development }\end{array}$ \\
\cline { 2 - 3 } & $\begin{array}{l}\text { Global Peace Index } \\
\text { Economic + social } \\
\text { development }\end{array}$ \\
\cline { 2 - 3 } & $\begin{array}{l}\text { Sustainable Develop- } \\
\text { ment Goals Index } \\
\text { (SDG Index) }\end{array}$ & $\begin{array}{l}\text { Economic + ecologi- } \\
\text { cal + social develop- } \\
\text { ment }\end{array}$ \\
\hline
\end{tabular}

Source: compiled on the basis of Kwatra et al., 2020; Schmidt-Traub et al., 2017

The modern understanding of sustainable development is linked primarily to the UN SDGs despite the criticisms of consistency and relevance of sub-indicators. The 17 SDGs and 169 targets are global and combine three patterns - economic growth, social integration and environmental protection in contrast to GDP per capita and other narrowly defined indicators. This index provides extensive assessment of countries' starting points according to internationally agreed goals (Schmidt-Traub et al., 2017). Thus, this study uses the SDGs as an indicator of sustainable development.

\section{Sustainable development map: egional distribution}

Many researchers discuss probability of SDGs achievement since these goals have become the key element of global development planning. Some scholars believe that the world will make only a limited progress towards achieving SDGs by 2030 with the current set of policy priorities. Klarin (2018) contends that many countries have not even come close to sustainable development, moreover, the regional disparity in achievement 
SDGs is significant (Moyer \& Hedden, 2020) and the gap between developed and developing countries has broadened (Klarin, 2018).

The Global SDGs Index measures the overall progress of countries towards all 17 sustainable goals; it is interpreted as a percentage of achievement. The score of $100(100 \%)$ means that all 17 SDGs have been achieved (Lafortune et al., 2018). According to the global sustainability index, European region (77.1\%) and North America (76.2\%) are the most successful in achieving the SDGs. Oceania region has 70.1 (\%), Latin America and the Caribbean - 68.4\%, Asia - 67.9\%, Africa only 53\% (Sachs et al., 2019; UN, 2019) (Figure 1).

Fundamental constraint of the implementation of sustainable development is significant variations in the degree of socio-economic development across countries (Klarin, 2018; Schmidt-Traub et al., 2017). To meet sustainability goals, less developed countries must make deal with such problems as extreme poverty, lack of access to essential infrastructure, environmental degradation and inequality in social integration (Schmidt-Traub et al., 2017). More economically developed countries face less but still significant challenges such as the climate change and its effects (Sinha et al., 2020), inequalities, and the loss of biodiversity.

Moreover, the map of global sustainability (see Figure 1) shows the fragmentation in the level of sustainable development in European countries. While most European countries have a GDP per capita higher than the world's average, these countries are highly developed and lead globally on the SDGs, but none are on track to the SDGs achievement (UN, 2019).

In most European countries, the whole range of strategic objectives aimed at the implementation of the SDGs is formulated in special national documents where the SDGs are adapted to local conditions (Ignatov et al., 2019). Lanshina et al. (2019) distinguished three key schemes for localizing the SDGs at the national level. The first approach is deep localization which includes consideration of all 17 SDGs and formulating goals at the national level. The second path is the implementation of the SDGs without formal localization, with no changes in sustainability strategies after the adoption of the 2030 Agenda. The third scheme is characterized by isolation from the 2030 Agenda and is characterized by the complete lack of localization. Germany is an example of complete localization, Sweden implements the SDGs without their formal localization, in Finland there is no localization.

The most desirable way to achieve the SDGs is the complete localization scheme. Moreover, the EU will integrate the SDG objectives into the annual review of EU member states' fiscal books (European Semester) (Lanshina et al., 2019). In Russia, the goals of strategic development reflected in the Presidential Order "On National Goals and Strategic Objectives of the Russian Federation until 2024" (Executive Order of May 2018). Most of the UN Sustainable Development Goals are almost fully included in Russia's medium- and long-term national strategy until 2024. Nevertheless, Sakharov \& Kolmar (2019) believe that Rus-

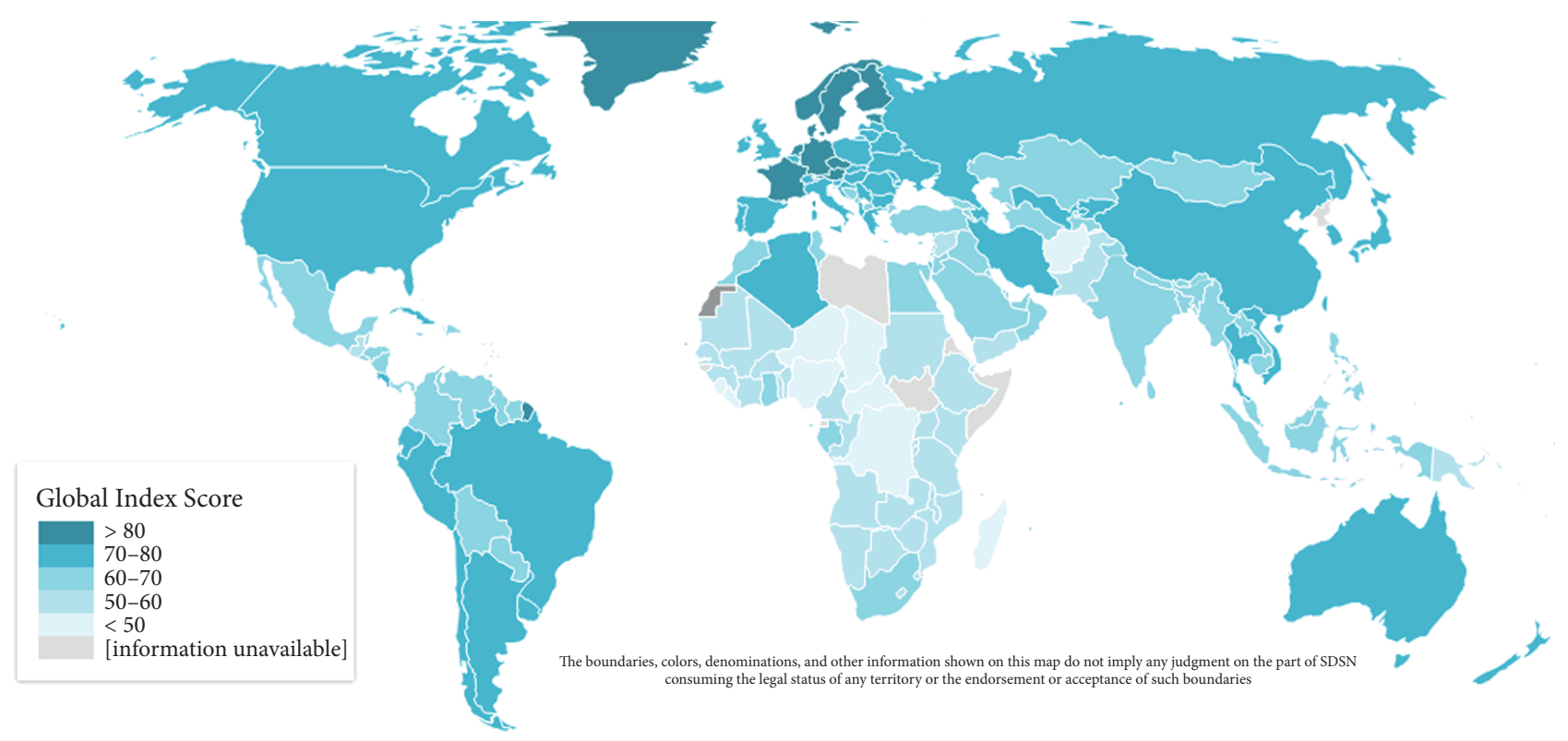

Figure 1. Global sustainability in the framework of the SDGs Index Source: Sachs et al., 2019; UN, 2019 
sia's strategy towards systematic implementation of the SDGs requires the inclusion of a full range of social issues in a comprehensive sustainable development strategy (Kolmar \& Sakharov, 2019).

Rydzewski (2015) discovered differences in the perception of sustainable development of residents of Eastern and Western European countries. In both Eastern and Western European countries people consider the social aspect of sustainability of vital importance. Western European countries are characterized by a much higher level of social capital. In addition, environmental issues are viewed as more important in Western Europe than Eastern Europe. Thus, in the case of Eastern European countries, the environmental pillar is clearly underestimated and the social pillar is weaker than in Western Europe.

The countries' development strategies should be balanced across the economic, social and environmental priorities taking into account political and economic goals on a global scale (Mensah \& Casadevall, 2019). Institutional governance positively contributes to the three pillars of sustainable development. Moreover, the three pillars affect each other, e.g. good governance moderates the positive impact of economic growth and human development; enhancing human development leads to lower carbon emissions (ecological factor) (Omri \& Mabrouk, 2020). Moreover, some SDG indicators will not be solved without a significant change in international aid policies. The most vulnerable countries must be the focus of international aid. Other constraints of sustainable development are the lack of financial resources, technology and innovation capacities (Klarin, 2018; Moyer \& Hedden, 2020; Schmidt-Traub et al., 2017). For instance, digitalization can be an effective factor of global sustainable development, thus it should be embedded into the business, government and society core statement (Lopatkova et al., 2019). However, different drivers and consequences of digitalization were revealed for different groups of countries. Digitalization has a positive effect on welfare in developed countries, while no influence was discovered in the group of developing countries. The positive impact of digitalisation is explained by the high level of inclusiveness of digital services, government and business investments, digital trust and literacy in developed countries (Zvereva et al., 2019).

Moreover, the effects of the novel coronavirus pandemic on the global economy and on sustainable development prospects are uncertain, but in the short term the outcomes are disastrous. The pandemic has exposed fundamental weaknesses in our global system such as weak health systems, lack of education, and lack of global cooperation. Evidence is emerging of the broader impact of the crisis on the desire to achieve the SDGs, e.g. according to the UNESCO, about 1.25 billion students are affected, which means a serious challenge to the achievement of the SDG 4 (Quality Education). According to the International Labour Organisation, about 25 million people may lose their jobs (SDG 8). In many parts of the world, the pandemic and its consequences are exacerbated by the difficulties in achieving poverty eradication (SDG 1) and food insecurity (SDG 2). As the world is trying to contain the spread of the virus and eliminate its negative impacts, countries are changing their priorities and reallocating resources. Thus, the level of SDGs achievement and global and national priorities may change drastically due to the pandemic 2019/20 (Solberg \& Akufo-Addo, 2020).

\section{Methods and data}

The study relies on descriptive statistical analysis of sustainability results reflected by the total country's SDG Index and achievement of separate 17 SDGs by European countries. The data were provided by sustainable development reports from 2016 to 2019 (Sachs et al., 2016-2019).

The research includes several stages. At the first stage, the dynamics and achievement of SDGs in 39 European countries were evaluated for the period of 2016- 2019 (Table 3).

Table 3

European Countries: Western and Eastern groups

\begin{tabular}{|c|c|}
\hline \multicolumn{2}{|c|}{ European Countries } \\
\hline Western & Eastern \\
\hline $\begin{array}{l}\text { Austria; Belgium; } \\
\text { Switzerland; Germany; } \\
\text { Denmark; Spain; } \\
\text { Finland; France; } \\
\text { United Kingdom; } \\
\text { Ireland; Iceland; Italy; } \\
\text { Luxembourg; Malta; } \\
\text { Netherlands; Norway; } \\
\text { Portugal; Sweden }\end{array}$ & $\begin{array}{l}\text { Albania; Bulgaria; Bosnia and } \\
\text { Herzegovina; Belarus; Czech } \\
\text { Republic; Estonia; Greece; } \\
\text { Croatia; Hungary; Lithuania; } \\
\text { Latvia; Moldova; North } \\
\text { Macedonia; Montenegro; } \\
\text { Poland; Romania; Russian } \\
\text { Federation; Serbia; Slovak } \\
\text { Republic; Slovenia; Ukraine }\end{array}$ \\
\hline
\end{tabular}

At the second stage, comparative analysis of sustainable development results in Western (18) and Eastern European (21) countries was conducted. The next step of empirical research is the identification of similarities and differences in 17 SDGs of Western and Eastern European countries. At the second and third stages, 
the parametric Student's t-distribution test and non-parametric $U$ Mann-Whitney test were conducted. At the final stage, the mapping of sustainable pillars in Western and Eastern European countries was conducted by dividing 17 SDGs into 3 categories - social, economic and environmental sustainability.

The calculations were conducted by using Excel and Stata software. The results are displayed in the form of graphs and tables.

\section{Results}

The SDG Index and Dashboards report (2019) show that the current achievement of the SDGs in Europe is below the average level (57\% of SDGs are significant and major problems). Only $8 \%$ of the goals are achieved by European countries. $33 \%$ means that European countries are making a significant contribution to goal achievement, but there still remain challenges in the implementation of the SDGs (Figure 2).

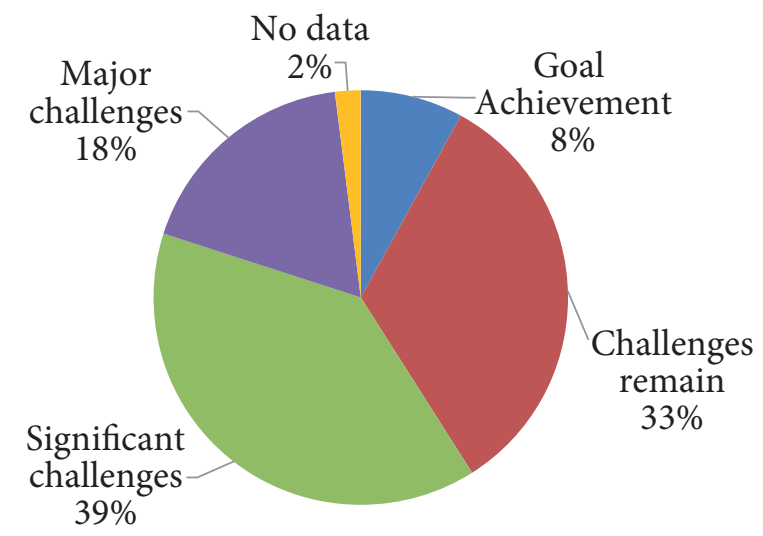

Figure 2. Achievement of the 17 SDGs in 39 countries in Europe (2019)

Source: Calculations are based on the SDG report (Sachs et al., 2019)

Moreover, the countries closest to achieving the SDGs in Western Europe are Denmark (85.2\%), Sweden (85\%), Finland (82.8\%), France (81.5\%), Austria (81.1\%), and Germany (81.1\%). At the bottom of the list in Western Europe is Luxemburg (74.8\%). As for Eastern European countries, the most successful in achieving the SDGs are the Czech Republic (80.7\%) and Estonia (80.2\%) while Montenegro has the worst rate (67.3\%).

Figure 3 illustrates the dynamic of sustainable development in two groups of European countries. The SDG Index is demonstrating a gradual growth for European countries. The overall sustainable ranking of Western European countries is higher than that of Eastern European countries.

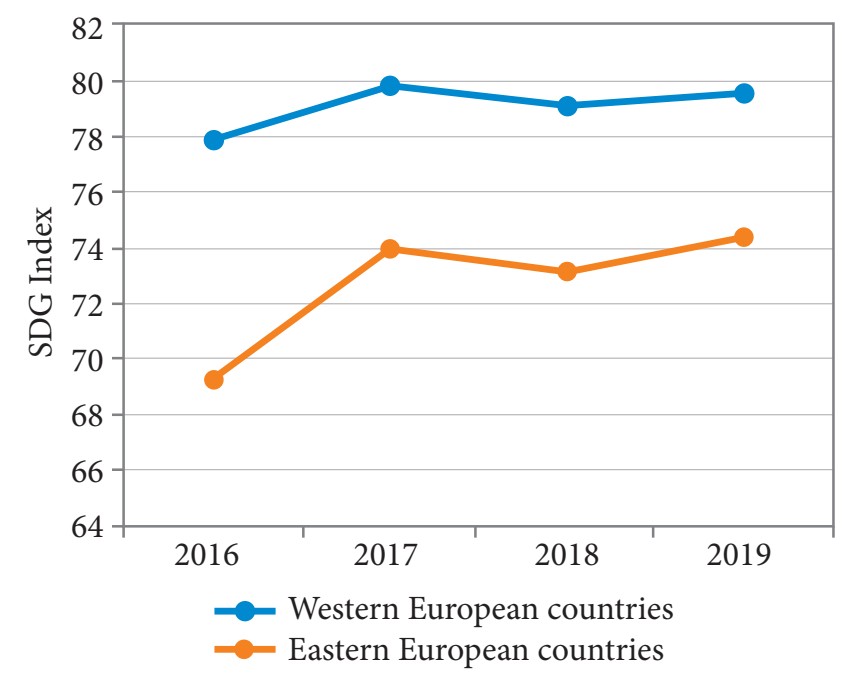

Figure 3. Dynamics of sustainable development in Western and Eastern European countries (2016-2019)

Source: Calculations are based on the SDGs reports (Sachs et al., 2016-2019)

However, the data indicate that the delta of sustainable growth in Eastern European countries is greater than in Western European countries. Sustainable growth from 2016 to 2017 and from 2018 and 2019 is higher in Eastern European countries than in Western European countries. Nonetheless, none of the Eastern European countries is included in the group of countries with a favorable situation in the sphere of sustainability (Raszkowski \& Bartniczak, 2019).

Our comparative analysis of sustainable development and SDGs achievement in Western and Eastern European countries is based on the Shapiro-Wilk criterion to estimate the conditions of the normal distribution of the sample. This test is better when used with small sample sizes (in our case 39 observations). According to the Shapiro-Wilk test, the null hypothesis cannot be rejected at the critical significance level of 0.05 , which means that the level of sustainable development (total SDG Index) follows the normal distribution pattern (Table 4).

Table 4

\section{Test of the normal distribution of European countries}

\begin{tabular}{|l|c|c|c|c|c|}
\hline \multicolumn{1}{|c|}{ Variable } & Obs & $\boldsymbol{W}$ & $\boldsymbol{V}$ & $\boldsymbol{z}$ & Prob > $\boldsymbol{z}$ \\
\hline SDG Index (Total) & 39 & 0.983 & 0.641 & -0.935 & 0.825 \\
\hline $\begin{array}{l}\text { SDG Index (Eastern } \\
\text { European countries) }\end{array}$ & 21 & 0.976 & 0.598 & -1.038 & 0.850 \\
\hline $\begin{array}{l}\text { SDG Index (Western } \\
\text { European countries) }\end{array}$ & 18 & 0.967 & 0.729 & -0.633 & 0.737 \\
\hline
\end{tabular}


Table 5

Dispersion equality test

\begin{tabular}{|c|c|c|c|c|c|c|}
\hline Group & Obs & Mean & Std. Err & Std. Dev & \multicolumn{2}{|c|}{ [95\% Conf. Interval] } \\
\hline SDG Index (Eastern European countries) & 21 & 74.395 & 0.825 & 3.781 & 72.674 & 76.116 \\
\hline SDG Index (Western European countries) & 18 & 79.622 & 0.694 & 2.943 & 78.159 & 81.086 \\
\hline Combined & 39 & 76.808 & 0.686 & 4.286 & 75.418 & 78.197 \\
\hline & \multicolumn{4}{|c|}{ ratio $=\operatorname{sd}($ est $) / \operatorname{sd}($ wes $)$} & \multicolumn{2}{|l|}{$f=1.6511$} \\
\hline & \multicolumn{4}{|c|}{ Ho: ratio $=1$} & \multicolumn{2}{|c|}{ degrees of freedom $=20,17$} \\
\hline & \multirow{2}{*}{\multicolumn{2}{|c|}{ Ha: ratio $<1$}} & \multicolumn{2}{|c|}{ Ha: ratio $!=1$} & \multicolumn{2}{|c|}{ Ha: ratio $>1$} \\
\hline & & & \multicolumn{2}{|c|}{$2^{\star} \operatorname{Pr}(F>f)=0.3005$} & \multicolumn{2}{|c|}{$\operatorname{Pr}(F>f)=0.1503$} \\
\hline
\end{tabular}

Source: the author's own calculations

The condition for equality of variances is met as the level of statistical significance 0.3 (Table 5).

To assess the level of sustainable development in the two samples of European countries we applied Student's t-distribution test, which showed that Western European and Eastern European countries are on different levels of sustainable development (Table 6).

Table 6

Sustainable development in Western and Eastern European countries; Mean (std. dev.)

\begin{tabular}{|l|c|c|c|c|}
\hline \multirow{2}{*}{ Dimension } & \multicolumn{2}{|c|}{ Groups of European countries } & \multirow{2}{*}{$\boldsymbol{t}$} & \multirow{2}{*}{$\boldsymbol{p}$} \\
\cline { 2 - 4 } & Eastern & Western & & \\
\hline SDG & $74.4(3.78)$ & $79.6(2.94)$ & -4.76 & 0.000 \\
\hline
\end{tabular}

Source: the author's own calculations

We used the parametric Student's t-distribution test and non-parametric U Mann-Whitney test to examine the similarities and differences in the achievement of the 17 SDGs in Western and Eastern European countries (Table 7). Different methods were used due to normal / non-normal distribution and dispersion equality / inequality. Western European countries are more active in SDGs 2, 3, 5, 7, 8, 9, 11 compared with Eastern countries. Eastern European countries achieved better results in SDGs 12 and 15. Eastern European countries face the greatest challenges on goals related to industry, innovation and infrastructure sustainability (SDG 9) and Western European countries, responsible consumption and production (SDG 12). On the other hand, both Western and Eastern countries demonstrate similar results in the achievement of SDGs 1, 4, 6, 10, 13, 14, 17 and 16. The best results of European countries were shown in SDG 1 ('no poverty').

Table 7

Sustainable directions in Western and Eastern European countries

\begin{tabular}{|c|c|c|c|c|c|}
\hline \multirow{2}{*}{ SDG } & \multicolumn{2}{|c|}{ Mean $(\bar{X})$ 1-100 } & \multirow{2}{*}{$Z(T)$} & \multirow{2}{*}{$\boldsymbol{P}$} & \multirow{2}{*}{ Test } \\
\hline & Western & Eastern & & & \\
\hline 1 No poverty & 99.6 & 99.0 & -0.909 & 0.363 & U Mann-Whitney \\
\hline 2 Zero hunger & 72.5 & 64.5 & -3.283 & 0.001 & U Mann-Whitney \\
\hline 3 Good health and well-being & 94.4 & 83.0 & -5.269 & 0.000 & U Mann-Whitney \\
\hline 4 Quality education & 91.9 & 89.1 & -1.883 & 0.068 & Student's T-test \\
\hline 5 Gender equality & 79.3 & 63.9 & -5.295 & 0.000 & Student's T-test \\
\hline 6 Clean water and sanitation & 87.3 & 89.4 & 1.198 & 0.231 & U Mann-Whitney \\
\hline 7 Affordable and clean energy & 89.4 & 82.4 & -3.874 & 0.000 & U Mann-Whitney \\
\hline 8 Decent work and economic growth & 85.6 & 70.3 & -4.705 & 0.000 & U Mann-Whitney \\
\hline 9 Industry, innovation and infrastructure & 74.4 & 40.3 & -8.406 & 0.000 & Student's T-test \\
\hline 10 Reduced inequalities & 85.3 & 82.4 & -0.713 & 0.481 & Student's T-test \\
\hline 11 Sustainable cities and communities & 87.6 & 79.1 & -4.100 & 0.000 & U Mann-Whitney \\
\hline 12 Responsible consumption and production & 50.9 & 67.1 & 4.648 & 0.000 & U Mann-Whitney \\
\hline 13 Climate action & 79.4 & 81.6 & 0.908 & 0.369 & Student's T-test \\
\hline 14 Life below water & 53.2 & 51.3 & -0.353 & 0.727 & Student's T-test \\
\hline 15 Life on land & 64.3 & 70.8 & 1.916 & 0.055 & U Mann-Whitney \\
\hline 16 Peace, justice and strong institutions & 83.0 & 65.6 & -4.635 & 0.000 & U Mann-Whitney \\
\hline 17 Partnership for the goals & 64.9 & 66.0 & 0.229 & 0.820 & Student's T-test \\
\hline
\end{tabular}

Source: the author's own calculations 
We also found differences in the SDGs clusters between the two groups of countries (Figure 4). Based on the Systemic Hierarchy of SDGs by Rockström (Stockholm Resilience Centre, 2016), we divided 16 SDGs into 3 groups - economic, environmental and social sustainability with the $17^{\text {th }}$ SDG being a separate partnership pillar. Thus, there are three clusters of SDGs: social $-1,2,3$, $4,5,7,11,16$; economic - $8,9,10,12$; environmental $-6,13,14,15$. We conducted mapping of social, economic, environmental sustainable directions by calculating the median value for each cluster.

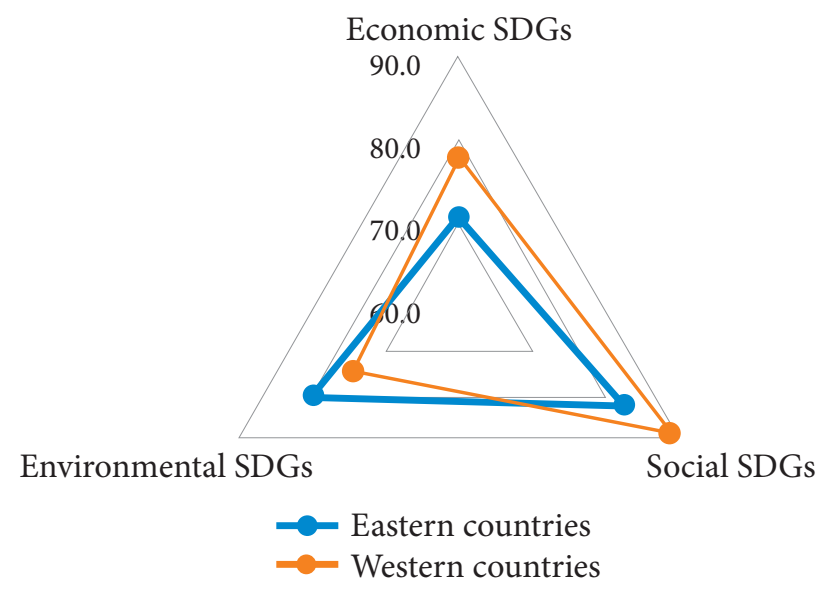

Figure 4. Mapping of sustainable approaches in Western and Eastern European countries

This procedure reveals that sustainable approach in Western Europe is achieved mostly in the sphere of the social and economic SDGs; in the Eastern European countries, social and environmental SDGs.

\section{Conclusions}

The global SDG index shows that even the wealthiest countries with high scores are facing difficulties in meeting their commitments in SDGs. While Europe leads globally on the SDGs, none of the countries are on track to the SDGs achievement. The overall sustainable ranking of Western European countries is higher than that of Eastern European countries due to different levels in social, environmental and economic spheres. Moreover, countries in Europe differ in their priorities and achievement of the SDGs. The global economy is shaping Western and Eastern European countries' efforts to adapt sustainable development goals under the influence of social, legal and other factors, including positive ones. Sustainable approach in Western European countries is achieved mostly in the social and economic SDGs; in Eastern European countries, in social and environmental SDGs. Competitiveness of Western European countries is provided by the state support and developed business sector, which determines the high economic level of the SDGs achievement. The question about the level of environmental initiatives in Eastern countries remains open. Some key manufacturers are attracted by the ideas of being green, but certification and/ or implementation of lean production processes requires considerable investment, which is why some companies choose to engage in greenwashing. The novel coronavirus pandemic has a huge impact on economy. The pandemic has exposed fundamental weaknesses of the global system. The response to the pandemic cannot be separated from SDGs. The effects of the pandemic are uncertain, but in the short term the outcomes are disastrous - the level of achievement of some SDGs may collapse. Thus, the world community has begun to change drastically their priorities at the global and national levels and redistribute resources. Fundamental obstacles to sustainable development are the insufficient degree of socio-economic development of many countries lacking both the necessary financial resources and technology as well as the diversity of political and economic goals on a global scale. Reaching SDGs requires dynamic multi-level governance, which means that converging of agendas, international aid and partnership, global awareness of the sustainable development process are likely to be the factors that would influence the achievement of SDGs.

\section{References}

Belyaeva, Zh., \& Lopatkova, Y. (2020) The Impact of Digitalisation and Sustainable Development Goals in SMEs Strategy: A Multi-Country European Study. The Changing Role of SMEs in Global Business: Contextual Evolution Across Markets, Disciplines and Sectors. Palgrave Studies in Cross-Disciplinary Business Research, In Association with EuroMed Academy of Business [in press]

Dang, H-A.H., \& Serajuddin, U. (2019). Tracking the sustainable development goals: Emerging measurement challenges and further reflections World Development, 127, Retrieved from https:// openknowledge.worldbank.org/handle/10986/31668. 
Diaz-Sarachaga, J.M., Jato-Espino, D., \& Castro-Fresno, D. (2018). Is the Sustainable Development Goals (SDG) index an adequate framework to measure the progress of the 2030 Agenda? Sustainable Development, 26, 663-671.

Ignatov, A.A., Mikhnevich, S.V., Popova, I.M., Safonkina, E.A., Sakharov, A. G., \& Shelepov, A.V. (2019). The approaches of leading donor countries to the implementation of the SDGs in national sustainable development strategies. Vestnik mezhdunarodnyh organizacij = Bulletin of International Organizations, 14 (1), 164-188. (In Russ.) doi: 10.17323/1996-7845-2019-01-10.

Karlstorm, C. (2018). The sustainable development goals - a framework for everyone, even SMEs. Retrieved from Royal Society for the encouragement of Arts, Manufactures and Commerce website https://www.thersa.org/discover/publications-and-articles/rsa-blogs/2018/06/the-sustainable-development-goals--a-framework-for-everyone-even-smes.

Klarin, T. (2018). The Concept of Sustainable Development: From its Beginning to the Contemporary Issues. Zagreb International Review of Economics and Business, 21, 67-94.

Kolmar, O., \& Sakharov, A. (2019) Prospects of Implementation of the UN SDG in Russia. International Organisations Research Journal, 14 (1), 189-206. doi: 10.17323/1996-7845-2019-01-11.

Kuznetsova, Yu.A. (2013). Stages of the formation and development of the concept of sustainable development. Molodoj uchenyj = Young scientist, 5, 337-339. (In Russ.)

Kwatra, S., Kumar, A., \& Sharma, P. (2020). A critical review of studies related to construction and computation of Sustainable Development Indices. Ecological Indicators, 112, doi: 10.1016/j. ecolind.2019.106061.

Lafortune, G., Fuller, G., Moreno, J., Schmidt-Traub, G., \& Kroll Ch. (2018) SDG Index and Dashboards Detailed Methodological paper. Retrieved from https://www.sdgindex.org/.

Lanshina, T., Barinova, V., Loginova, A., Lavrovsky, E., \& Ponedelnik I. (2019) Localizing and Achieving the Sustainable Development Goals at the National Level: Cases of Leadership. International Organisations Research Journal, 14 (1), 207-224. doi: 10.17323/1996-7845-2019-01-12.

Lopatkova, Y., Belyaeva, Zh., \& Sohag, K. (2019, September). Global sustainability and digitalization linkage. Paper presented at the Proceedings of the 12th Annual Conference of the EuroMed Academy of Business: Business Management Theories and Practices in a Dynamic Competitive Environment. Greece (1719-1722). EuroMed Press.

Mensah, J., \& Casadevall, S. R. (2019) Sustainable development: Meaning, history, principles, pillars, and implications for human action: Literature review. Cogent Social Sciences, 5, doi: $\underline{10.1080 / 23311886.2019 .1653531 .}$.

Miola, A., \& Schiltz, F. (2019). Measuring sustainable development goals performance: How to monitor policy action in the 2030 Agenda implementation? Ecological Economics, 164, doi: 10.1016/j.ecolecon.2019.106373.

Moyer, J.D., \& Hedden, S. (2020). Are we on the right path to achieve the sustainable development goals? World Development, 127, doi: 10.1016/j.worlddev.2019.104749.

Omri, A., \& Mabrouk, N.B. (2020). Good governance for sustainable development goals: Getting ahead of the pack or falling behind?, Environmental Impact Assessment Review, 83, doi: 10.1016/j. eiar.2020.106388.

Raszkowski, A., \& Bartniczak, B. (2019). Sustainable Development in the Central and Eastern European Countries (CEECs): Challenges and Opportunities. Sustainability, 11, doi: $\underline{10.3390 /}$ su11041180.

Rydzewski, P. (2015). Sustainable Development as Seen by the Residents of Eastern and Western Europe on the Basis of ISSP Environment Data. Problemy Ekorozwoju, 10, 49-53.

Sachs, J., Schmidt-Traub, G., Kroll, C., Durand-Delacre, D. \& Teksoz, K. (2016): An SDG Index and Dashboards - Global Report. New York: Bertelsmann Stiftung and Sustainable Development Solutions Network (SDSN).

Sachs, J., Schmidt-Traub, G., Kroll, C., Durand-Delacre, D. and Teksoz, K. (2017): SDG Index and Dashboards Report 2017. New York: Bertelsmann Stiftung and Sustainable Development Solutions Network (SDSN).

Sachs, J., Schmidt-Traub, G., Kroll, C., Lafortune, G., \& Fuller, G. (2019). Sustainable Development Report 2019. New York: Bertelsmann Stiftung and Sustainable Development Solutions Network (SDSN). 
Sachs, J., Schmidt-Traub, G., Kroll, C., Lafortune, G., \& Fuller, G. (2018): SDG Index and Dashboards Report 2018. New York: Bertelsmann Stiftung and Sustainable Development Solutions Network (SDSN).

Schmidt-Traub, G., Kroll, C., Teksoz, K., Durand-Delacre, D., \& Sachs, J.D. (2017). National baselines for the Sustainable Development Goals assessed in the SDG Index and Dashboards. Nature Geoscience, 10 (8), 547-555.

Secundo, G., Ndou, V., Del Vecchio, P., \& De Pascale G. (2020). Sustainable development, intellectual capital and technology policies: A structured literature review and future research agenda. Technological Forecasting and Social Change, 153, doi: 10.1016/j.techfore.2020.119917.

Sinha, A., Sengupta, T., \& Alvarado, R. (2020). Interplay between technological innovation and environmental quality: Formulating the SDG policies for next 11 economies, Journal of Cleaner Production, 242, doi: 10.1016/j.jclepro.2019.118549.

Solberg E., \& Akufo-Addo N. (2020). Why we cannot lose sight of the Sustainable Development Goals during coronavirus. Retrieved from World economic forum website https://www.weforum. org/agenda/2020/04/coronavirus-pandemic-effect-sdg-un-progress/.

Stockholm Resilience Centre (2016). Sustainable development goals. Retrieved from https:// www.stockholmresilience.org/research/research-news/2016-06-14-how-food-connects-all-thesdgs.html.

UN (2019). Sustainable Development Goals Report. Retrieved from https:/unstats.un.org/sdgs/ report $/ 2019 /$.

United Nations (2015) Transforming our world by 2030: A new agenda for global action Zero. Draft of the outcome document for the UN Summit to adopt the Post-2015. Development Agenda. New York: United Nations.

Visseren-Hamakers, I.J. (2020). The $18^{\text {th }}$ Sustainable Development Goal, Earth System Governance, 3, 100047, doi: 10.1016/j.esg.2020.100047.

Zvereva, A.A., Belyaeva, Zh.S., \& Sohag, K. (2019). Influence of economic digitalization on well-being in developed and developing countries. Economy of Region, 15 (4), 1050-1062, doi: 10.17059/2019-4-7.

\section{Information about the author}

Yana A. Lopatkova - Assistant Lecturer, Graduate School of Economics and Management, Ural Federal University named after the first president of Russia B.N. Yeltsin (19 Mira Str., 620002 Ekaterinburg, Russia); e-mail: iana.lopatkova@urfu.ru

ARTICLE INFO: received August 1, 2020; accepted October 30, 2020

\section{Информация об авторе}

Лопаткова Яна Алексеевна - ассистент, Институт экономики и управления, Уральский федеральный университет имени первого президента России Б.Н. Ельцина (Россия, 620002, Екатеринбург, ул. Мира, 19); e-mail: iana.lopatkova@urfu.ru

ИНФОРМАЦИЯ О СТАТЬЕ: дата поступления 1 августа 2020 г.; дата принятия к печати 30 октября 2020 г. 